\title{
Rearing Pattern of Bannur Sheep in its Home Tract
}

\author{
H.P. Dinakar, K. Satynarayan, V. Jagadeeswary, M. Harisha* and Anant Rao Desai \\ Department of Veterinary and Animal Husbandry Extension Education, Veterinary College, \\ Shivamogga-577204, Karnataka, India \\ *Corresponding author
}

\section{Keywords}

Rearing pattern, Bannur sheep, Constraints, Sheep rearing

Article Info

Accepted:

12 May 2019

Available Online:

10 June 2019

\section{A B S T R A C T}

Bannur or Mandya sheep breed has been one of the most important and dominant indigenous breed of Karnataka. Bannur breed has been in limelight ever since its development and continues to be the only outstanding and the best Mutton breed of the State and Country. An exploratory research design was adopted to study the rearing pattern of Bannur sheep in its native tract and thus 200 respondents from Malavalli and Bannur villages were selected purposively for the study. The study revealed that all the farmers clean their sheep sheds regularly but do not apply any ecto-parasite solution while cleaning sheep sheds. Related to identification of animals, all the farmers identify their flock by marking with colors. Majority of the farmers posses closed type of housing usually house with mud walls and roof made up of cheaply available materials. Majority of the farmers prefer early and late hours of the day for grazing their flock during summer and depend on rivers as a source of drinking water for their flocks. Majority of the farmers graze their flocks for 6 to 7 hours a day. Majority of the farmers allowed the rams for first service at the age of 12-14 months and change their breeding rams regularly.

\section{Introduction}

Livestock sector plays a crucial role in sustainable contribution to rural development in the state. It is closely integrated with the existing farming system on mutually exclusive basis and interdependence with each other for augmenting food and nutritional security of farm households and socio-economic status in the society by utilizing all available agriculture waste, byproducts and common property resources. It is the best insurance against the vagaries of nature due to drought, famine and other natural calamities. Livestock contributes by way of milk and meat production. It enhances soil fertility and crop production through their manure and urine. It also provides additional economic goods like skin, hides wool etc., for trade and commerce activities. Besides, they render services in the form of animal power in croplands, carrying of agriculture goods and transportation of people. In addition, they provide year round gainful employment and dispersed risks evenly and greatly thus minimize the suicidal attitude of the farmers. Sale of livestock products provides timely revenue. Hence sheep and goats are treated as 
"moving banks" at rural places for immediate cash revenue which enable to purchase crop inputs as well as to finance other farm investments. Thus livestock plays a vital role in enhancing the economic viability and sustainability of farming systems.

According to Livestock Census, Department of Animal Husbandry, Dairying \& Fisheries, Ministry of Agriculture (2012), India has got 190.90 million cattle, 108.70 buffaloes, 65.06 million sheep and 135.17 million goats. Majority of India's population lives in rural areas, consequently there is likely to be more pressure on land as almost all the village population depends on agriculture, resulting in an unfavorable land man ratio. Owing to the population explosion and with the increasing pressure on land, agriculture alone cannot provide gainful employment to all the rural population. Therefore, allied activities like animal husbandry will have to be viewed as effective instrument for supplementing the income and providing employment to the weaker sections in rural areas.

The domestication of animals was noticed during the Neolithic times along with the cultivation of cereals. Sheep and Goat husbandry was practiced by man earlier to crop husbandry, because it provided him ready source of food and clothing. Sheep have an inseparable identity with the farmers in India from time immemorial. They constitute an important component of agriculture and economy of the farming community in India, especially those of the weaker sections among agriculturists.

They form substantial income particularly by the sale of surplus ram lambs, wool, unproductive and aged animals and manure. The migratory sheep are folded in the harvested croplands of the farmers during night hours and in return they get either food grains or price for the manure.
Sheep is an important livestock species of India as they contribute greatly to the farmers' economy, especially in rural areas. They play an important role in the livelihood of small and marginal farmers and landless labourers as they provide regular and sustainable income. Sheep in India are maintained mainly on common grazing lands, crop residues and tree leaves.

Bannur sheep also called as Bandur or Mandya breed has been acclaimed to be one of the most important and dominant indigenous breeds of Karnataka and India. Its meat is being treated at National and International spectrum of sheep products as most nutritious and high quality mutton in the diets of human beings. Bannur breed of sheep is pre-dominantly distributed in Mandya and adjacent districts. Bannur breed has been in limelight ever since its development and continues to be the only outstanding mutton breed. This breed was used as one of the parental indigenous breed to develop other improved breeds.

Bannur sheep in its home tract over centuries implies not only its inherent adaptability but also confirms its multi-utility under different farming systems of the native tracts. This breed has been evolved naturally for adaptation to semi-arid region for both dry land agriculture and also irrigated areas. This has ability to survive and sustain prolong periods of drought, semi-starvation and thirst, but cannot travel long stretches of grazing land due to short legs because of which the sheep movement is restricted to small local area. Thus, this breed has made stamping impression on the society and the farmers in the native tract. However because of various reasons, the Bannur sheep is under the verge of extinction, thus a systematic investigation would help the farmers and the policy makers to arrive at a decision in conserving this valuable breed of sheep. Keeping all these in 
view the present study was under taken assess rearing pattern of Bannur sheep in its home tract.

\section{Materials and Methods}

An exploratory research design was adopted for the study to formulate a problem for more precise investigation and to develop working hypothesis from an operational point of view. The study was conducted in the state of Karnataka as it was one among the important states in the country with highest livestock population. The different school of thoughts suggest that the native tract of Bannur sheep were both Bandur village of Malavalli taluk, Mandya district and Bannur village of $T$. Narasipur taluk, Mysore district, hence both the districts were purposively selected for the study.

In Malavalli and T. Narasipur taluk ten villages each were randomly selected. In each selected village ten farmers who are rearing Bannur sheep were randomly selected. A total of 200 Bannur sheep rearing farmers constituted as the sample for the study. The interview schedule was developed in consultation with experts for data collection. The respondents were personally interviewed using pre-tested interview schedule. It was made sure that all questions were selfexplanatory and each of the farmers was interviewed in their vernacular language personally by the investigator. The data collected was coded, tabulated and subjected to the statistical tools like frequency, percentage etc. to draw the results and inferences.

\section{Results and Discussion}

The data presented in Table 1, related to Sheep rearing practices followed by the Bannur sheep rearers revealed that cent per cent of the respondents clean the sheds daily but none of the respondents use ectoparasitic solutions for cleaning the shed. With respect to washing of sheep half $(50.00 \%)$ of the respondents wash sheep once in one to two months followed by washing once in month $(29.50 \%)$ and washing of sheep once in 3-4 months $(20.50 \%)$. All the respondents are following the shearing of wool in sheep during the months of January/June.

A perusal of Table 2, revealed that the majority of the farmers identify their flock by marking with colors. Majority $(95.50 \%)$ of the farmers posses closed type of housing, usually house with mud walls and roof made up of cheaply available materials. The majority $(97.50 \%)$ of these houses were having less ventilation and possess mud flooring.

All the respondents revealed that they don't take any other extra managemental practices during summer season except taking the sheep flock for grazing during early and late hours of the day for grazing. Majority $(64.00 \%)$ of the farmers depends on rivers as a source of drinking water for their flocks followed by 16 per cent depends on Canal water and others (20\%) depend on bore well and other sources.

Further 50.50 per cent of the farmers graze their flocks for 6 to 7 hours a day, while 49.50 per cent of the farmers graze their flocks for $7-8$ hours a day and majority $(80.50 \%)$ of the respondents revealed that the sheep were given dried horse gram and horse gram husk after returning from grazing while 19.50 per cent of the farmers provide leaves from fodder trees. The findings of the present study were in consonance with the findings of Yadav and Khada (2009), Gupta et al., (2011) and Sakthivel et al., (2012) who reported that goats were mostly housed in thatched shed with mud flooring. They were fed tree leaves, crop residues and the fodder. 
Table.1 Sheep rearing practices followed by the Bannur sheep rearers

\begin{tabular}{|r|l|l|c|c|}
\hline \multicolumn{2}{|c}{ Category } & \multicolumn{1}{c|}{ Response } & \multicolumn{2}{c|}{ Respondents } \\
\cline { 4 - 6 } & & & F & \% \\
\hline $\mathbf{1}$ & Daily cleaning of sheep shed & Yes & 200 & $\mathbf{1 0 0}$ \\
\hline $\mathbf{2}$ & $\begin{array}{l}\text { Spraying ecto-parasitic solution while cleaning } \\
\text { sheep shed }\end{array}$ & Yes & 0 & $\mathbf{0}$ \\
\hline $\mathbf{3}$ & Frequency of washing sheep & 1 month & 59 & $\mathbf{2 9 . 5 0}$ \\
\hline & & $1-2$ months & 100 & $\mathbf{5 0 . 0 0}$ \\
\hline $\mathbf{4}$ & Frequency of sheep shearing in a year & J-4 months & 41 & $\mathbf{2 0 . 5 0}$ \\
\hline
\end{tabular}

Table.2 Rearing practices of Bannur sheep

$(\mathrm{N}=200)$

\begin{tabular}{|c|c|c|c|c|}
\hline \multirow[t]{2}{*}{ No. } & \multirow[t]{2}{*}{ Category } & \multirow[t]{2}{*}{ Response } & \multicolumn{2}{|c|}{ Respondents } \\
\hline & & & $\mathbf{F}$ & $\%$ \\
\hline \multirow[t]{2}{*}{1} & \multirow[t]{2}{*}{ Flock Identification } & Ear tags & 0 & $\mathbf{0}$ \\
\hline & & Marking with colors & 200 & 100 \\
\hline \multirow[t]{2}{*}{2} & \multirow[t]{2}{*}{ Housing } & Open type & 9 & 4.50 \\
\hline & & Closing type & 191 & 95.50 \\
\hline \multirow[t]{2}{*}{3} & \multirow[t]{2}{*}{ Floor surface } & Rough & 5 & 2.50 \\
\hline & & Mud floor & 195 & 97.50 \\
\hline \multirow[t]{2}{*}{4} & \multirow{2}{*}{$\begin{array}{l}\text { Management practices during } \\
\text { summer }\end{array}$} & Yes & 0 & $\mathbf{0}$ \\
\hline & & No & 200 & 100 \\
\hline \multirow[t]{3}{*}{5} & \multirow{3}{*}{ Water management } & Canal water & 32 & 16.00 \\
\hline & & River water & 128 & 64.00 \\
\hline & & Bore well and Other Sources & 40 & 20.00 \\
\hline \multirow[t]{2}{*}{6} & \multirow[t]{2}{*}{ Grazing hours per day } & 6-7 hours & 101 & 50.50 \\
\hline & & 7-8 hours & 99 & 49.50 \\
\hline \multirow[t]{2}{*}{7} & \multirow[t]{2}{*}{ Type of fodder given at shed } & Horse gram & 161 & 80.50 \\
\hline & & Fodder trees & 39 & 19.50 \\
\hline
\end{tabular}

@ Multiple Response

Table.3 Responses on breeding rams management

\begin{tabular}{|c|l|l|c|c|}
\hline \multirow{2}{*}{ No. } & \multicolumn{1}{|c|}{ Category } & \multicolumn{2}{c|}{ Response } & \multicolumn{2}{c|}{ Respondents } \\
\cline { 3 - 5 } & & F & $\mathbf{1 0}$ \\
\hline $\mathbf{1}$ & Age at first service of & $10-12$ months & 22 & $\mathbf{1 1 . 0 0}$ \\
\cline { 2 - 5 } & Ram lambs & $12-14$ months & 178 & $\mathbf{8 9 . 0 0}$ \\
\hline $\mathbf{2}$ & Change breeding Rams & Yes & 76 & $\mathbf{6 4 . 5 0}$ \\
\hline $\mathbf{3}$ & $\begin{array}{l}\text { If Yes, Frequency of } \\
\text { Change of Rams }\end{array}$ & $<2$ years & 53 & $\mathbf{3 8 . 0 0}$ \\
\cline { 2 - 5 } $\mathbf{4}$ & $\begin{array}{l}\text { Common abnormalities } \\
\text { 2-4 years }\end{array}$ & $\begin{array}{l}\text { Less vigor \& } \\
\text { Cryptorchidism }\end{array}$ & 200 & $\mathbf{1 0 0}$ \\
\hline
\end{tabular}


Table.4 Rearing practices in lambs

\begin{tabular}{|c|c|c|c|c|}
\hline \multirow[t]{2}{*}{ No. } & \multirow[t]{2}{*}{ Lambs } & \multirow[t]{2}{*}{ Response } & \multicolumn{2}{|c|}{ Respondents } \\
\hline & & & $\mathbf{F}$ & $\%$ \\
\hline \multirow[t]{3}{*}{1} & \multirow[t]{3}{*}{ Age at Puberty } & 8-10 months & 81 & 40.50 \\
\hline & & 11-12 months & 100 & 50.00 \\
\hline & & 13-15 months & 19 & 9.50 \\
\hline \multirow[t]{3}{*}{2} & \multirow[t]{3}{*}{ Age at first mating } & 8-10 months & 54 & 27.00 \\
\hline & & $11-12$ months & 129 & $\mathbf{5 9 . 5 0}$ \\
\hline & & 13-15 months & 27 & 13.50 \\
\hline \multirow[t]{2}{*}{3} & \multirow[t]{2}{*}{ Age at first lambing } & $11-12$ months & 91 & 45.50 \\
\hline & & 13-15 months & 109 & 54.50 \\
\hline \multirow[t]{2}{*}{4} & \multirow[t]{2}{*}{ Days Open } & 2-3 months & 185 & 92.50 \\
\hline & & 4-6 months & 15 & 7.50 \\
\hline \multirow[t]{2}{*}{5} & \multirow[t]{2}{*}{ Gestation period } & 5 months & 198 & 99.00 \\
\hline & & 6 months & 2 & 1.00 \\
\hline \multirow[t]{2}{*}{6} & \multirow{2}{*}{$\begin{array}{l}\text { Number of Offspring's in each } \\
\text { Lambing }\end{array}$} & $10 r 2$ & 5 & 2.50 \\
\hline & & One & 195 & 97.50 \\
\hline \multirow[t]{4}{*}{7} & \multirow[t]{4}{*}{ Common Abnormalities } & Abortion & 200 & 100 \\
\hline & & Retention of Placenta & 199 & 99.50 \\
\hline & & Still Birth & 192 & 96.00 \\
\hline & & Early lamb mortality & 192 & 96.00 \\
\hline
\end{tabular}

The data regarding the management of breeding rams were presented in Table 3 . The findings revealed that majority $(89.00 \%)$ of the farmers allowed the rams for the first service at the age of 12-14 months. Only 11 per cent of the farmers allowed the rams as early as 10-12 months. Majority of the farmers $(64.50 \%)$ change their breeding rams regularly whereas others $(35.50 \%)$ do not change the rams as they continue with same ram for long period of time. Out of 64.50 per cent respondents who change their breeding ram, 38 per cent of the farmers change within 2 years and 26.50 per cent of the farmers change between 2 to 4 years. Less vigor and cryptorchidism in the breeding rams were the common abnormalities observed by all the respondents.

The observations recorded regarding the management of lambs were tabulated in Table 4. Regarding the age at puberty of lambs, 50 per cent of the farmers opined that the lambs attain puberty at the age of 11 to 12 months, 40.50 per cent of the farmers opined 8 to 10 months and other 9.5 per cent opined 13 to 15 months. Further 59.50 per cent of the farmers allowed the lambs for first mating at the age of 11 to 12 months, 27 per cent of the farmers allowed as early as 8 to 10 months and the remaining 13.50 per cent allowed at the age of 13 to 15 months. Majority (54.50\%) of the farmers opined that the age at the first lambing will be as early as 13 to 15 months and the other 45.50 per cent of the farmers opined of 11 to 12 months. Majority (92.50\%) of the farmers opined days open as 2 to 3 months and only 7.50 per cent of farmers opined 4 to 6 months. Majority $(99.00 \%)$ of the farmers observed the gestation period as 5 months and only 1 per cent opined as more than 5 months. Majority (97.50\%) of the farmers indicated that only one offspring was produced in each lambing and a meager per 
cent $(2.50 \%)$ of the respondents reported that sheep do offer two offspring sometimes. All the respondents reported that the common abnormalities found during parturition were abortion, followed by retention of placenta (99.50\%), still birth and early lamb mortality (96.00\%). These findings of the present study are in agreement with the findings of Yadav and Khada (2009), Tanwar et al., (2007) who reported that Animal come in heat generally during monsoon season. Single birth was common and placenta was disposed off either by throwing or by burring in heap of dirt.

\section{References}

Gupta D.C., Suresh A. and Sethi, D., 2011, Economics of sheep and goat rearing in semi-arid region of Rajasthan. The Indian Journal of Small Ruminants, 17(2): 215-221
Livestock Census, 2012. Department of Animal Husbandry, Dairying \& Fisheries, Ministry of Agriculture. Government of India.

Sakthivel, K.M., Narmatha, N., Akila, N and Uma, V., 2012. Management practices followed by goat farmers in Namakkal district of Tamil Nadu. The Indian Journal of Small Ruminants, 18(1): 125128

Tanwar, P.S., Vaishanava, C.S. and Jain, L.S., 2007. Studies on housing and breeding management practices adopted by goat owners in tribal areas of Udaipur district. Indian Journal of Animal Research. 41(1): 59-61

Yadav C. M. and Khada B. S., 2009. Management practices and performance of goats in tribal belt of Dungarpur district in Rajasthan. The Indian Journal of Small Ruminants 15(1): 131-133

\section{How to cite this article:}

Dinakar, H.P., K. Satynarayan, V. Jagadeeswary, M. Harisha and Anant Rao Desai. 2019. Rearing Pattern of Bannur Sheep in its Home Tract. Int.J.Curr.Microbiol.App.Sci. 8(06): 14161421. doi: https://doi.org/10.20546/ijcmas.2019.806.171 